UPPSALA UNIVERSITET

Working Paper 2009:7

Department of Economics

\title{
Dividend taxation, share repurchases and the equity trap
}

Tobias Lindhe and Jan Södersten 
Department of Economics

Working paper 2009:7

Uppsala University

May 2009

P.O. Box 513

ISSN $1653-6975$

SE-751 20 Uppsala

Sweden

Fax: $+{ }_{4} 6184711478$

DIVIDEND TAXATION, SHARE REPURCHASES AND

THE EQUITY TRAP

TOBIAs LindHE AND JAN SÖDERSTEN

Papers in the Working Paper Series are published on internet in PDF formats.

Download from http://www.nek.uu.se or from S-WoPEC http://swopec.hhs.se/uunewp/ 


\title{
DIVIDEND TAXATION, SHARE REPURCHASES AND THE EQUITY TRAP
}

\begin{abstract}
This paper reconsiders the effects of dividend taxation. Particular attention is paid to the form of the "equity trap", that is, the extent to which cash paid to the shareholders must be taxed as dividends. Our analysis shows that Sinn's (1991) criticism of the well-known King and Fullerton (1984) methodology for underestimating the cost of new share issues amounts to a misleading comparison across two different regimes for the equity trap. Contrary to Sinn, we find that when dividends are paid following a new issue, as assumed by King-Fullerton, the cost of capital is higher than is the case when no dividends are paid.
\end{abstract}

Keywords: dividend taxation, share repurchases, equity trap, cost of capital, nucleus theory, growth path

JEL Code: H24, H25, H32

\section{Tobias Lindhe}

Uppsala Center for Fiscal Studies (UCFS)

Department of Economics

Uppsala University

Tobias.Lindhe@bredband.net

\author{
Jan Södersten* \\ Department of Economics \\ Uppsala University \\ Box 513, 75120 Uppsala, Sweden \\ Jan.Sodersten@nek.uu.se
}

May 2009. We are grateful to Michael Riis Jacobsen and Guttorm Schjelderup as well as to other participants of The Research Forum on Taxation at Holmsbu, Norway, June 12-14, 2006 for valuable comments on an earlier version of this paper (Lindhe and Södersten, (2006)), and to Vesa Kanniainen and Chuan-Zhong Li for helpful suggestions.

*Corresponding author. 


\section{Introduction}

The economic consequences of dividend taxation have been the subject of a continuing debate among public finance researchers for more than a quarter of a century. Much of this discussion has been concerned with whether the "new" or "old" view of dividend taxation best describes its effects. ${ }^{1}$ A crucial difference between the two views is in the source of equity finance used at the margin by the corporate firm. Under the new view, or "trapped equity" model, the marginal source of equity is retained earnings. As the dividend tax reduces the opportunity cost to the shareholders of an additional unit of profits retained for investment in the same proportion as it reduces future dividends, the dividend tax has no impact on investment incentives. Under the old view, the dividend tax falls also on marginal investment projects. Though the exact interpretation of the old view varies between different researchers, a common assumption is that the firm is unable to cut dividends to finance new investment projects or finds it costly to do so. ${ }^{2}$ With new issues of shares rather than retained profits as the marginal source of equity, the shareholders' opportunity cost of investment is not mitigated by the dividend tax, and as a result, the tax reduces the rate of return to investment.

That the dividend tax falls on marginal investments financed by new issues of equity is, however, accepted also by holders of the "new" view. "New" view- models typically state that the cost of new share issues equals the shareholders' after-tax rate of return requirement adjusted for the total tax - at the corporate and personal levels - levied on distributed profits. A useful reference here is the study by King and Fullerton (1984) whose formulae for the cost of capital has been put to a widespread use in international comparisons and for policy oriented research. ${ }^{3}$

Some time ago, however, Sinn (1991a) claimed that the distortion from dividend taxation is larger than the conventional formulae such as those derived in King and Fullerton (ibid.) suggest. Sinn's point, also argued in Sinn (1991c), is that care must be taken to distinguish not only between alternative sources of finance but also, and equally important, between alternative uses for profit.

\footnotetext{
${ }^{1}$ The new view of equity was developed by Auerbach (1979), Bradford (1981) and King (1977). For a survey of the debate, see Auerbach (2002) and Auerbach and Hassett (2002, 2005).

${ }^{2}$ See Auerbach (2002).

${ }^{3}$ See for example OECD (1991) and EU (2001).
} 
To derive the cost of equity, Sinn (1991a) sets up a model of an all-equity firm, with a personal tax on dividends as the only tax parameter. Share repurchases are ruled out, leaving dividends and internal investment as the only possible uses of profits. The outcome of this model is a "nucleus" theory of the corporation. A firm faced by an initial shortage of retainable profits following a disturbance to the marginal productivity of capital, will let the shareholders inject less than the total amount of funds needed to reach a new long-run equilibrium. Once the "nucleus" of new equity has been obtained, the firm embarks upon a growth path using less expensive retained earnings. The firm then continues to grow by internal funds, issuing no more shares, and paying no dividends until the marginal productivity of capital is equated to the rate of interest.

Though no parametric expression for the cost of new equity is obtained from this analysis, Sinn finds, for "mild assumptions" about the form of the firm's production function, that the marginal productivity of capital subsequent to the issue of new equity is higher than suggested by King and Fullerton (1984) and others ${ }^{4}$. Sinn’s explanation to this result is that the King-Fullerton methodology invariably assumed that profits from marginal investment projects were distributed as dividends ${ }^{5}$, rather than used for internal investment.

Sinn's "nucleus” theory, or life-cycle model of the firm, is widely cited, and his claim that conventional formulae understate the cost of equity funds seems not to be questioned. Still, the King-Fullerton equations have remained the generally accepted basis for measuring incentive effects of taxes on income from capital, and over the past decades a vast literature has emerged which has developed the original model in various directions. ${ }^{6}$ There are hence two competing views in the literature regarding the impact of taxation on the cost of equity funds.

This paper reconsiders the effects of dividend taxation on the cost of new share issues. We conclude that Sinn's criticism of conventional formulae for underestimating the cost of new equity is misleading and is in fact a comparison between apples and oranges. The reason for this is that Sinn and King-Fullerton make use of different assumptions not only about

\footnotetext{
${ }^{4} \operatorname{Sinn}(1991 \mathrm{a})$, p. 284.

${ }^{5}$ Ibid., p.285.

${ }^{6}$ See for example, Chennells and Griffith (1987), Jorgenson and Landau (1993), Devereux and Griffith (2003), Sørensen (2004).
} 
dividend behavior following a new issue of equity (as Sinn points out) but also, and more importantly, about the "equity trap", that is, the extent to which cash paid by the firm to the shareholders must be taxed as dividends. In Sinn’s model, new share issues are constrained to be non-negative, and share repurchases (and other forms of a tax-free recovery of equity) are ruled out. The cost-of-capital expressions of the King-Fullerton type instead implicitly rely on the opposite assumption, namely that shareholders are allowed a tax-free recovery of original capital contributed through new share issues. This means that new share issues never fall into the equity trap.

This fundamental difference in assumptions about the equity trap, that is, the design of the tax code, explains Sinn's finding that the cost of new share issues is higher than the conventional King-Fullerton formulae suggest. In fact, the King-Fullerton assumption that dividends are paid subsequent to a new issue, does not cause a downward bias in estimating the cost of capital, as Sinn argues. With dividends being paid in the year following the new issue, the cost of capital rather turns out to be higher than is the case when the firm behaves optimally (what is optimal behavior depends on the equity trap).

The remainder of this paper is organized as follows. In section 2 we set up a dynamic model of an all equity firm, where, as in Sinn (ibid.), a personal tax on dividends is the only tax parameter. To some extent, the firm may avoid the equity trap, through a tax-free recovery of original capital. In the present model, this is equivalent to repurchasing own shares, and we model a constraint on share repurchases which reflects rules in force within the European Union. We derive a general expression for the cost of capital, where the results of Sinn and King-Fullerton appear as special cases. For comparison with our general model, section 3 presents a brief review of Sinn's (1991b) analysis of share repurchases, where Sinn assumes a fixed proportion between share repurchases and dividends. The optimal behavior of the firm following a new issue of equity is determined in section 4, which also reports on numerical simulations to compare the firm's behavior under different assumptions about the equity trap. Section 5 concludes.

\section{The model}


We derive the firm's cost of capital by setting up a dynamic model in discrete time with a personal tax on dividends $\tau$ as the only tax parameter. The owner is assumed to maximize the after-tax dividend stream, net of new share issues and share repurchases, given by

$$
\sum_{s=t}^{\infty} \frac{\theta D_{s}-N_{s}+R_{s}}{(1+r)^{s-t}},
$$

where $D$ denotes dividends as defined in the firm's accounts, $N$ is the amount of new share issues, $R$ is the current flow of share repurchases, $r$ is the discount rate and $\theta$ is the after-tax value of a unit of dividends, $\theta \equiv 1-\tau$. The firm's budget constraint in period $s$ is a cash flow identity, where capital inflow equals capital outflow

$$
F\left(K_{s-1}\right)+N_{s}=D_{s}+I_{s}+R_{s}
$$

The production function $F(K)$ depends only on the stock of capital, where the stock in period $s-1$ becomes fully efficient in production in period $s$. To keep the model simple, capital depreciation is ignored, which implies that the stock of capital evolves over time as

$$
K_{s-1}+I_{s}=K_{s} .
$$

As usual, dividends must be non-negative

$$
D_{s} \geq 0 \text {, }
$$

and we also require issues of new equity to be non-negative

$$
N_{s} \geq 0 \text {. }
$$

A Council Directive first adopted in 1976, and later amended in November 1992, regulates the use of share repurchases for companies within the European Union ${ }^{7}$. Present rules state

\footnotetext{
${ }^{7}$ The Second Council Directive on Company Law, Directive 77/91/EEC on the formation of public limitedliability companies and the maintenance and alteration of their capital (13.12.1976). Amendments: Directive 92/101/EEC (23.11.1992).
} 
that own shares acquired by a company may not exceed 10 percent of the subscribed capital. To capture this rule and examine its impact on the cost of capital, we introduce a variable $A$ which is the stock of past equity injections (the firm's share capital), and a variable $G$ defined as the stock of current and past share repurchases. Variable $A$ evolves as

$$
A_{s-1}+N_{s}=A_{s}
$$

and $R$ and $G$ are related through the motion

$$
G_{s-1}+R_{s}=G_{s}
$$

where $^{8}$

$$
R \geq 0 \text {, }
$$

and

$$
G_{s} \leq \alpha A_{s} .
$$

This means that the firm may own at most a fraction $\alpha$ of its own share capital (EU law requires $\alpha \leq 0.1$ ).

The model defines a discrete-time control problem with control variables $N, D, R$ and $I$, and state variables $K, A$ and $G$. By imposing shadow values for the constraints and motions $-\mu^{D}$ for (2), $\mu^{K}$ for (3), $\mu^{A}$ for (6), $\mu^{G}$ for (7), $\lambda^{D}$ for (4), $\lambda^{N}$ for (5), $\lambda^{R}$ for (8), $\lambda^{G}$ for (9) and maximizing the owners' after-tax dividend stream the optimization problem takes the form $\max \sum_{s=t}^{\infty} \frac{\Lambda(\cdot)}{(1+r)^{s-t}}$. The $\Lambda$-function reads as

\footnotetext{
${ }^{8}$ Alternatively, we could allow the firm to reverse past re-purchases, that is, to sell previously acquired shares, $R<0$. However, to prevent the firm from circumventing restriction (9), by substituting negative re-purchases for regular new share issues, this would require that we also impose the restriction $G_{s} \geq 0$.
} 


$$
\begin{aligned}
\Lambda & =\theta D_{s}-N_{s}+R_{s}+\mu_{s}^{D}\left(F\left(K_{s-1}\right)+N_{s}-I_{s}-D_{s}-R_{s}\right) \\
& +\mu_{s}^{K}\left(K_{s-1}+I_{s}-K_{s}\right)+\mu_{s}^{A}\left(A_{s-1}+N_{s}-A_{s}\right)+\mu_{s}^{G}\left(G_{s-1}+R_{s}-G_{s}\right) \\
& +\lambda_{s}^{D} D_{s}+\lambda_{s}^{N} N_{s}+\lambda_{s}^{R} R+\lambda_{s}^{G}\left(\alpha A_{s}-G_{s}\right) .
\end{aligned}
$$

The first order conditions with respect to the state and control variables are

$D_{s} \quad \theta-\mu_{s}^{D}+\lambda_{s}^{D}=0$

$I_{s} \quad-\mu_{s}^{D}+\mu_{s}^{K}=0$,

$K_{s} \quad-\mu_{s}^{K}+\frac{\mu_{s+1}^{K}}{1+r}+\frac{\mu_{s+1}^{D}}{1+r} F_{K_{s}}=0$.

$N_{s} \quad-1+\mu_{s}^{D}+\mu_{s}^{A}+\lambda_{s}^{N}=0$,

$A_{s} \quad-\mu_{s}^{A}+\frac{\mu_{s+1}^{A}}{1+r}+\alpha \lambda_{s}^{G}=0$

$R_{\mathrm{s}} \quad 1-\mu_{\mathrm{s}}^{D}+\mu_{\mathrm{s}}^{G}+\lambda_{\mathrm{s}}^{R}=0$

$G_{s} \quad-\mu_{s}^{G}+\frac{\mu_{s+1}^{G}}{1+r}-\lambda_{s}^{G}=0$

Equations (12) and (13) yield the general expression for the cost of capital

$$
F_{K_{s}}=\frac{\mu_{s}^{K}(1+r)-\mu_{s+1}^{K}}{\mu_{s+1}^{K}},
$$

that is, the cost of capital is determined by the rate of interest and the marginal valuation of capital, $\mu^{K}$, for two consecutive periods. 


\subsection{The long-run cost of capital}

For a firm that relies on retained earnings as the marginal source of finance and also pays dividends, the shadow value of the dividend constraint appearing in (4) is zero, $\lambda^{D}=0$. Since $\mu^{K}=\mu^{D}$ (eq. 12), the first order condition for $D$ (eq. 11) then implies that in long-run equilibrium, $\mu_{s}^{K}=\mu_{s+1}^{K}=\theta$. The general expression for the long-run cost of capital in (18) is therefore

$$
F_{K}=r
$$

With $\mu^{K}=\theta$, the owner is indifferent between retaining earnings and receiving dividends, and as a result of this, the dividend tax does not distort the steady state value of the firm's capital stock. This is the well-known result from the new view of equity.

\subsection{New equity as the marginal source of funds}

New shares are issued by the firm only occasionally as a response to exogenous disturbances to the productivity of capital when retained earnings are insufficient to finance the required addition to the capital stock. A firm hit by a productivity shock in period $t$ will issue new shares (with $\lambda_{t}^{N}=0$ ) sufficiently to depress the marginal value of equity to unity. In this model, as seen from equation (14), this marginal value comes from two conceptually different sources, $\mu^{K}+\mu^{A}=1$. The first is the direct increase in the productive capacity of the firm, which is valued at the shadow price of capital, $\mu^{K}\left(=\mu^{D}\right.$, see eq. 13). The second derives from the fact that the new equity to some extent (depending on $\alpha$ ) enables the owner a taxfree return of capital, valued at the shadow price $\mu^{A}$.

Solving equations (15) and (17), we find that $\mu_{s}^{A}=-\alpha \mu_{s}^{G}$. With $\mu^{K}=\mu^{D}$ and with $\lambda_{t}^{N}=0$ when $N_{t}>0$, equation (14) may then be written as

$$
\mu_{t}^{K}=1-\mu_{t}^{A}=1+\alpha \mu_{t}^{G}
$$

Since $\mu_{t+1}^{G}=\mu_{t}^{G}(1+r)$ when constraint (9) does not bind, equations (16) and (17) give that 


$$
\mu_{t}^{G}=-\frac{1-\mu_{t+1}^{K}+\lambda_{t+1}^{R}}{1+r}
$$

Combining (20) and (21) further yields

$$
\mu_{t}^{K}=1-\frac{\alpha\left(1-\mu_{t+1}^{K}+\lambda_{t+1}^{R}\right)}{1+r} .
$$

Finally, by inserting (22) into (18), we derive

$$
F_{K_{t}}=\frac{1+r-\alpha\left(1-\mu_{t+1}^{K}+\lambda_{t+1}^{R}\right)-\mu_{t+1}^{K}}{\mu_{t+1}^{K}},
$$

which is the cost of capital when the firm issues new shares at time $t$. It is clear from equations (22) and (23) that for a given shadow price of capital, $\mu_{t+1}^{K}$, allowing for sharerepurchases ( $\alpha>0$ ), or other forms of tax-free distributions of cash, reduces the cost of capital. However, since the marginal value of capital in the period subsequent to the new issue, $\mu_{t+1}^{K}$, cannot be determined without further assumptions, no parametric expression for the cost of capital is available.

\subsection{Sinn’s (1991a) results reconsidered}

When the firm is not allowed to own its own shares (or is otherwise not allowed to undertake tax-free distributions of cash), $\alpha=0$, the model above is a discrete-time version of Sinn's (1991a) continuous-time model. Equation (23) then simplifies to

$$
F_{K_{t}}=\frac{1+r-\mu_{t+1}^{K}}{\mu_{t+1}^{K}}
$$

which corresponds to Sinn's expression for the cost of new equity.

One of the important conclusions from Sinn's analysis is that, for "mild assumptions” about the form of the firm's production function, the cost of capital subsequent to an issue of new 
equity is higher than obtained from the expression for new equity derived by King- Fullerton and others, that is

$$
F_{K_{t}}=\frac{(1+r)-\mu_{t+1}^{K}}{\mu_{t+1}^{K}}>\frac{r}{1-\tau} .
$$

Sinn further claims that earlier research underestimated the true cost of equity because of the assumption that profits from marginal investment projects invariably were distributed as dividends.

A first question here concerns the validity of Sinn's explanation to inequality (25). In the present discrete-time version of Sinn's model, it is straight-forward to determine the cost of capital in case the firm pays dividends in the year following the new issue. With $\mu_{t+1}^{K}=\theta$ when dividends are paid, and with $\theta \equiv 1-\tau$, expression (24) simplifies to ${ }^{9}$

$$
F_{K_{t}}=\frac{r+\tau}{1-\tau}
$$

The assumption that the firm pays dividends in the year following the new issue hence does not turn the general expression for the cost of new share issues as derived by Sinn (1991a), i.e. equation (24), into King-Fullerton's expression for cost of new equity, $r /(1-\tau)$. Moreover, since the shadow value $\mu_{t+1}^{K}>\theta$, when no dividends are paid in the year following the new issue, the cost of capital in (24) is actually lower than in the case where the firm does pay dividends, that is $\frac{(1+r)-\mu_{t+1}^{K}}{\mu_{t+1}^{K}}<\frac{r+\tau}{1-\tau}$.

Sinn's explanation to inequality (25) is therefore wrong, or at best, incomplete. Although the assumed dividend behavior does affect the cost of capital, there is actually a more fundamental difference in assumptions between Sinn (1991a) and King and Fullerton (1984) that drives the analysis of how the dividend tax affects the cost of capital. This difference in assumptions will be explained below.

\footnotetext{
${ }^{9}$ Expression (26) corresponds to a result derived by Auerbach (1983, p. 925).
} 
With $\alpha=1$, i.e. where the firm is allowed to repurchase outstanding shares (or is otherwise allowed to undertake tax-free distributions of cash) to the extent of its contributed capital, it is straightforward to show that the shadow price $\lambda_{t+1}^{R}$ in (23) is zero ${ }^{10}$. The cost of capital then turns out to be

$$
F_{K_{t}}=\frac{r}{\mu_{t+1}^{K}}
$$

This equation further simplifies when the firm pays dividends following the new issue. With $\mu_{t+1}^{K}=\theta$ and $\theta \equiv 1-\tau$, we get

$$
F_{K_{s}}=\frac{r}{1-\tau} \text {. }
$$

Equation (28) is immediately recognized as King-Fullerton's expression for the cost of capital with new share issues! It is also clear that with $\mu_{t+1}^{K}>\theta$, the cost of capital in (27) is lower than in (28).

The obvious conclusion from the above analysis is that Sinn's criticism of the King-Fullerton model for underestimating the cost of new share issues is misleading. The two expressions for the cost of capital which Sinn compares in his analysis turn out to differ not only in terms of the assumed dividend behavior, but also, and more fundamentally, by representing different tax regimes. Sinn's model explicitly assumes that $\alpha=0$, while King-Fullerton's approach may be viewed as a special case of a regime with $\alpha=1$. The assumption that profits from marginal investment projects are paid as dividends (as in King-Fullerton) does affect the cost of capital, but the direction of this effect is opposite to that suggested by Sinn: With no dividends being paid in the year following the new issue, the cost of capital is lower than is the case when the firm pays dividends. This conclusion holds irrespective of the extent to which the firm may escape the equity trap through share repurchases or other forms of taxfree recovery of initial equity.

\footnotetext{
${ }^{10}$ Adding the first order conditions (14) and (16) and using that $\mu_{s}^{A}=-\alpha \mu_{s}^{G}$ gives $\lambda_{s}^{N}+\lambda_{s}^{R}=\frac{1-\alpha}{\alpha} \mu_{s}^{A}$. Since $\lambda_{s}^{N} \geq 0$ and $\lambda_{s}^{R} \geq 0$, it is clear that with $\alpha=1$ it must hold that $\lambda_{s}^{N}=0$ and $\lambda_{s}^{R}=0, \forall s$.
} 


\section{Dividends and share repurchases in fixed proportions (Sinn 1991b)}

The model presented in section 2 allows the firm to freely choose both the timing and amount of share repurchases, subject to an upper limit of the type implied by current EU regulations. In his earlier contribution Share repurchases, the 'new' view and the cost of capital, Sinn (1991b) chooses a different approach by imposing a fixed relationship between cash dividends and share repurchases. This section briefly explains Sinn's approach and relates it to the model in section 2. As in section 2, we ignore both corporate taxation, and shareholder taxation of capital gains ${ }^{11}$.

With share repurchases $(R)$, the firm's budget constraint (previously given by eq. 2 above) is

$$
X_{s} \equiv D_{s}+R_{s}=F\left(K_{s-1}\right)+N_{s}-I_{s},
$$

and Sinn's assumption that cash distributions to the shareholders are split in fixed proportions between dividends $(\gamma)$ and share repurchases, $(1-\gamma)$, implies that $D_{s}=\gamma X_{s}$ and $R_{s}=(1-\gamma) X_{s}$. The firm's objective function with share re-purchases becomes (cf. eq. 1)

$$
\sum_{s=t}^{\infty} \frac{\theta \gamma X_{s}+(1-\gamma) X_{s}-N_{s}}{(1+r)^{s-t}},
$$

where $X$ is the total cash flow paid to the shareholders (given in 39) and $\theta \equiv 1-\tau$ is the aftertax value of a unit of dividends. Using (39), this is

$$
\sum_{s=t}^{\infty} \frac{(1-\gamma \tau)\left(F\left(K_{s-1}\right)+N_{s}-I_{s}\right)-N_{s}}{(1+r)^{s-t}} .
$$

Sinn's assumption that the total cash paid to the shareholders is split in fixed proportions between cash dividends and share repurchases (taxed at a preferential rate, untaxed in this case), is therefore equivalent to disregarding share repurchases and introducing an overall

\footnotetext{
${ }^{11}$ Sinn's model includes both corporate taxation (with a split rate system) and personal taxation of capital gains. Simplifying the analysis by ignoring these taxes does not affect the character of the results, however.
} 
reduction in the tax burden on dividends, from $\tau$ to $\gamma \tau$. The adjusted "tax rate" $\gamma \tau$ is simply a weighted average of the tax on dividends, $\tau$, and the zero tax on share repurchases, using the proportions $\gamma$ and $1-\gamma$ as weights. Given this insight (also expressed in Sinn (1991b)), it is obvious that the new view's result for the long-run marginal productivity of capital remains valid, but also that the long-run marginal valuation of equity will equal unity minus the adjusted "tax rate" $\gamma \tau$.

That the new view's conclusion regarding the marginal valuation of equity must be revised in the presence of share repurchases is not due to share repurchases per se, however, but rather to Sinn's special assumption that dividend payments and share repurchases occur in fixed proportions. When the firm, as in section 2 above, is allowed to optimize the timing of both share repurchases and dividends, share repurchases will precede the payment of dividends, as we demonstrate in section 4 below. As a result, the long-run marginal valuation of equity is $1-\tau$, that is, the new view's valuation result is fully preserved.

\section{Optimal behavior and the firm's growth path}

We next turn to analyzing the firm's optimal behavior following a new issue of equity. We first describe how the incentives faced by the firm depend on the share-repurchase parameter $\alpha$, and we then proceed to illustrate the behavior of the firm making use of a few numerical simulations.

In Sinn's (1991a) case, where all cash distributions to shareholders must be taxed as dividends ( $\alpha=0$ ), the firm will issue new shares sufficient to depress the marginal valuation of capital, $\mu^{K}$, to unity ${ }^{12}$. As was briefly described in section 1 above, optimal behavior is then to embark upon a growth path using less expensive retained earnings. As long as $\mu^{K}>\theta$ the firm continues to grow by internal funds, issuing no more shares, and paying no dividends. This process ends when the marginal productivity of capital is equated to the rate of interest and the marginal valuation of capital equals unity minus the dividend tax rate, $\mu^{K}=1-\tau \equiv \theta$. Readers looking for a more detailed and formal treatment of this case are referred to Sinn's paper.

\footnotetext{
${ }^{12}$ The starting condition is $\mu_{t}^{K}+\mu_{t}^{A}=1$, where $\mu_{t}^{A}=0$ when $\alpha=0$. For further explanation, see section 2 .
} 
In those cases where share repurchases or other forms of a tax-free return of original equity are allowed ( $\alpha>0)$, the starting condition is, likewise, that the marginal valuation of the injection of new equity funds equals unity. However, as explained in section 2, this marginal valuation comes from two conceptually different sources. The first is the direct increase in the productive capacity of the firm, which is valued at the shadow price of capital, $\mu^{K}$. The second derives from the fact that the new equity to at least some extent enables the owner a tax-free return of capital, valued at the shadow price $\mu^{A}$.

In the special case with $\alpha=1$, we find that $\lambda_{s}^{N}=0$ and $\lambda_{s}^{R}=0, \forall s$, as shown in footnote (11). From equations (12) and (14) it is then clear that the condition $\mu^{K}+\mu^{A}=1$ will hold all along the firm's optimal path, with $\mu^{K}$ falling from its initial value in period $t$ in the range $\theta<\mu_{t}^{K}<1$, to its long-run value of unity minus the dividend tax rate. As in Sinn's case (with $\alpha=0$ ) no dividends will be paid as long as $\mu_{s}^{K}>\theta$. This leaves in turn two possible uses of profits, subsequent to the new issue: for investment and for share repurchases.

With $\alpha=1$ it is straight-forward to demonstrate that additions to the capital stock are not compatible with the first-order conditions, as long as the stock constraint on share repurchases is not binding, $G_{s}<A_{s}$. As seen from the general expression for the firm's cost of capital (eq. 18), the marginal value of capital will decrease from the current period to the next, $\mu_{s+1}^{K}<\mu_{s}^{K}$, when the marginal productivity of capital is higher than its long-run value, i.e. the rate of interest. Since the cost of capital with $\alpha=1$ and a non-binding stock constraint on share repurchases is $F_{K_{s}}=r / \mu_{s+1}^{K}$ (see eq. 27), this decrease in the marginal valuation of capital between periods $s$ and $s+1$ also implies a rise in the marginal productivity of capital and, hence, a decrease in the capital stock, $K_{s+1}<K_{s}$. With a new issue in period $t$, the first order conditions therefore rule out the possibility that the firm would use current profits in the following period $t+1$ for investment, which would add to the capital stock.

The only feasible use of profits for period $t+1$ is therefore for repurchasing of shares, and by the reasoning above these repurchases will be financed both by current profits and some disinvestment. This process of repurchasing will continue during the following periods until the stock constraint on share repurchases (eq. 9) binds. The firm will then switch to retaining 
profits earned in subsequent periods and add to its capital stock. This second phase corresponds to the growth path analyzed by Sinn, where the firm continues to grow by internal funds, paying no dividends until the new long-run equilibrium is reached.

When the constraint parameter $\alpha$ is in the interval $0<\alpha<1$ optimal behavior is different. With $\mu_{t}^{G}=-\frac{\mu_{t}^{A}}{\alpha}$ (eqs. 15 and 17) and $\mu^{K}=\mu^{D}$, equation (16) may be re-written as

$$
1-\mu_{t}^{K}-\frac{\mu_{t}^{A}}{\alpha}+\lambda_{t}^{R}=0
$$

Since the firm's starting condition is $\mu_{t}^{K}+\mu_{t}^{A}=1$, equation (16') implies that $\lambda_{t}^{R}>0$ for $0<\alpha<1$, that is, the non-negativity constraint on share repurchases binds. The firm wants to engage in negative share repurchases (i.e. selling previously acquired shares) to finance the required addition to the capital stock, but of course it cannot. Assuming ${ }^{13}$ that this incentive remains for the following period $t+1$, we also rule out (positive) share repurchases as a use of profits for $t+1$. With no dividends and no share repurchases, the firm will start on a growth path, financed by internal funds, just as in Sinn's case (with $\alpha=0$ ). This internally financed growth will cause the marginal valuation of capital to fall over time and eventually the incentive for negative share repurchases will vanish, that is $\mu_{s}^{K}+\frac{\mu_{s}^{A}}{\alpha}=1$. This means that the firm is indifferent between retaining earnings and repurchasing shares, and as a result, the firm enters a phase where current profits will be used for share repurchases. This second phase continues until the stock constraint on share repurchases will bind, $G=\alpha A$. With $\mu^{K}>\theta$, the firm then enters a third phase, where profits again are used for investment. This final growth phase ends when the marginal valuation of capital equals its long-run value, $\mu^{K}=\theta$, and the marginal productivity of capital equals the interest rate.

\footnotetext{
${ }^{13}$ On theoretical grounds we cannot rule out the possibility that $\mu_{t+1}^{K}+\frac{\mu_{t+1}^{A}}{\alpha}=1$. In this case the firm would start by repurchasing shares at time $t+1$, just as in the case with $\alpha=1$. However, in the numerical simulations reported below for $0<\alpha<1$, we have not been able to detect any path, which both begins with share repurchases and is compatible with the first-order conditions. This suggests that it is reasonable to assume that $\mu_{t+1}^{K}+\frac{\mu_{t+1}^{A}}{\alpha}>1$, i.e. the firm will start growing following a new share issue.
} 


\subsection{Numerical simulations}

The differences in behavior between firms facing different possibilities to repurchase shares or using other forms of tax-free return of new equity - may be further clarified by way of numerical simulations. We will assume that there occurs an exogenous disturbance to the firms that raises the marginal productivity of capital, and that the resulting investment needs cannot be financed from retained earnings.

We refer to Appendix for a step-by-step account of the simulations. In general terms, we make use of the first order conditions to determine the development over time of the marginal valuation of capital, $\mu^{K}$, the pre-tax marginal rate of return, $F_{K}$, the capital stock, $K$, and in the case where $\alpha>0$ - the stock of new equity, $A$, and the stock of share repurchases, $G$. We specify the firm's production function in Appendix and we assume that the market rate of interest is 5 percent. For the set of parameters chosen, the long run capital stock is 100 .

The results of the simulations are illustrated in figures 1-2 for a dividend tax rate of 30 per cent ( $\tau=0.3$ ). We show how the parameter $\alpha$ affects the cost of capital and the firm's capital stock. Following a capital injection in period $t$, the cost of capital evolves over time back to its long run value of 5 percent in period $t+13$. For $\alpha=1$, the cost of capital is initially 6.22 percent, or 1.24 times its long run value, compared to 12,75 percent, or 2.55 times the long run value, when $\alpha=0$.

Figure 1. The cost of capital following a new share issue for different values of $\alpha$ and $\tau=0.3$. 


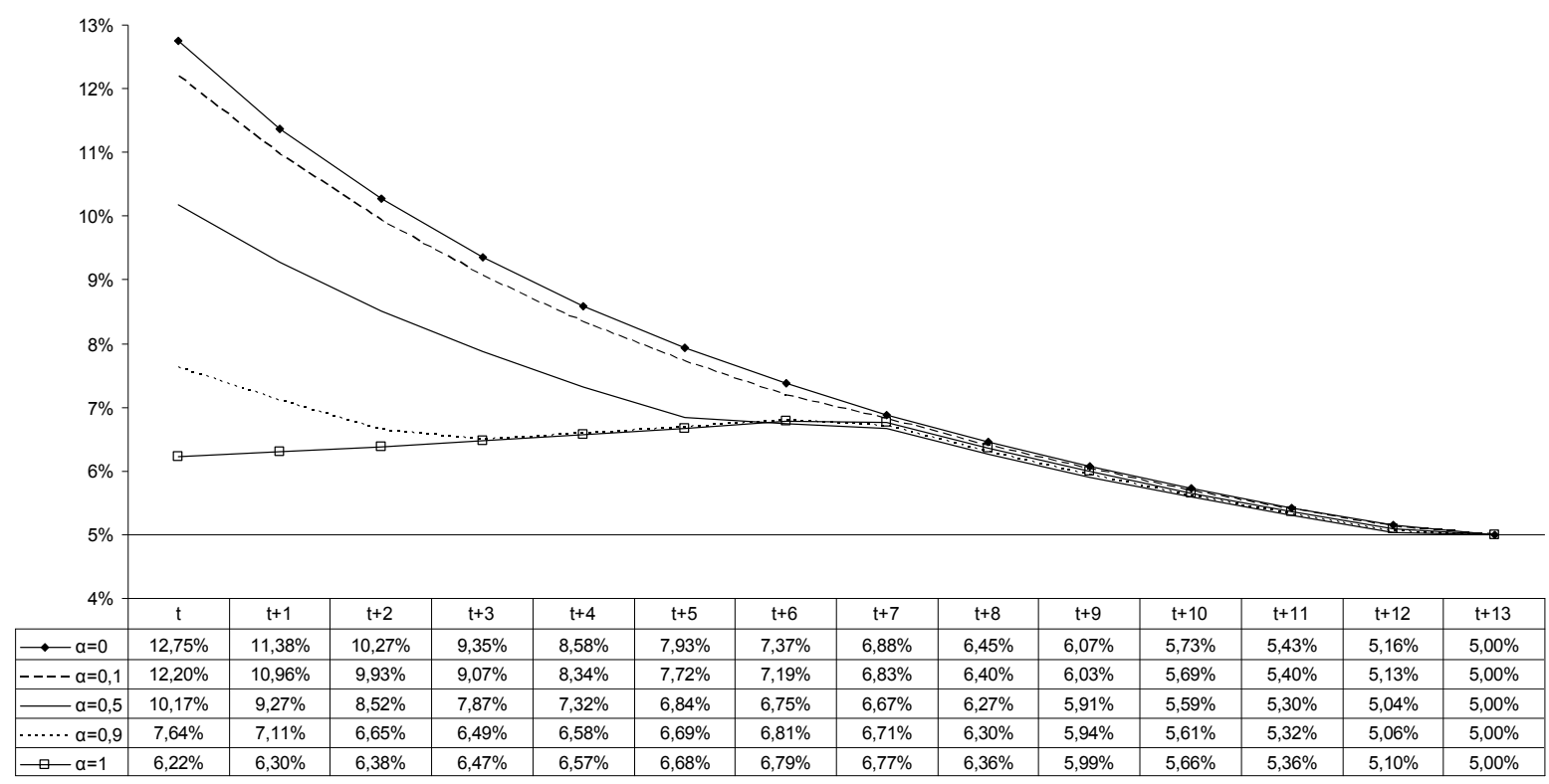


Figure 2. The stock of capital following a new share issue for different values of $\alpha$ and $\tau=0.3$

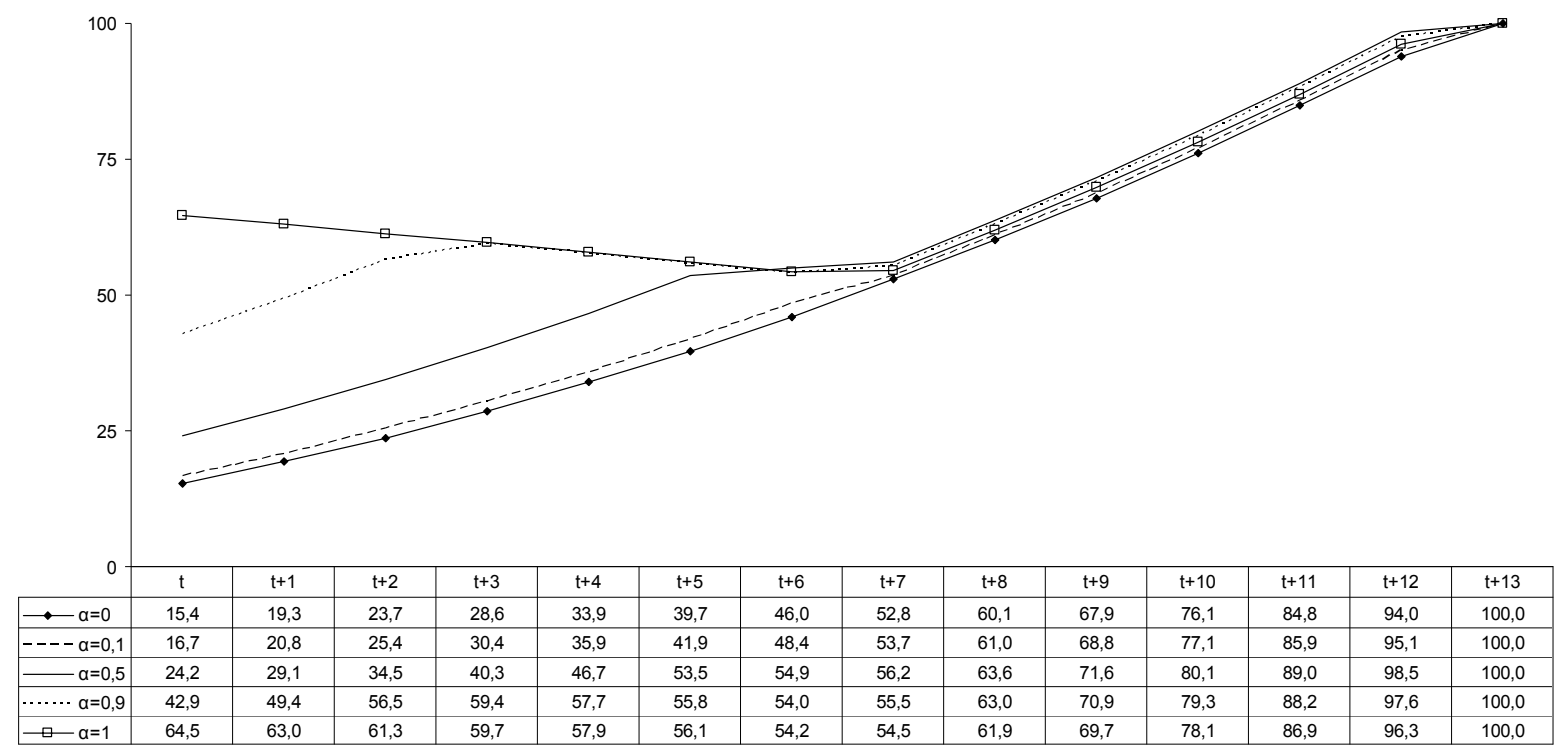

As a result of these differences, there is a striking difference in the amount of new equity injected by the shareholders. The initial new issue is more than 4 times as large when $\alpha=1$ as it is when $\alpha=0$ (64.5 vs. 15.4). Following the new issue, the firm uses all profits for internal investment when $\alpha=0$, and completes its growth path in 13 years. The adjustment phase when $\alpha=1$ is of approximately the same length, but during the first half of this phase, the firm uses both current profits and disinvestment to return the original new equity by way of share repurchases.

The intermediate cases where $0<\alpha<1$ are illustrated for $\alpha=0,1, \alpha=0,5$ and $\alpha=0,9$. On theoretical grounds we are not able to rule out the possibility that the firm will start by repurchasing shares (as when $\alpha=1$ ). The numerical simulations strongly indicate, however, that the firm, following the injection of capital, will instead embark upon an investment path (as when $\alpha=0$ ), see footnote 14 . This initial growth phase is then followed by a phase of share repurchases (as when $\alpha=1$ ). When the firm has repurchased the amount of shares allowed by the tax code (as determined by $\alpha$ ), a second phase of investment follows on the firm's way towards long-run equilibrium. We also find, as is clearly seen in figure 2 , that the lower the parameter $\alpha$, the longer is the first investment phase and the shorter is the phase of share repurchases. 
Figures 3 and 4 give the corresponding results when the dividend tax rate is 15 percent ( $\tau=0.15$ ). A tax cut reduces the cost of new equity and increases the size of the initial equity injections. In general, a cut in the tax rate also makes the adjustment periods shorter, and this effect is stronger the lower is $\alpha$. The distorting effects of dividend taxation remain larger, however, the lower is $\alpha$.

Figure 3. The cost of capital following a new share issue for different values of $\alpha, \tau=.15$.

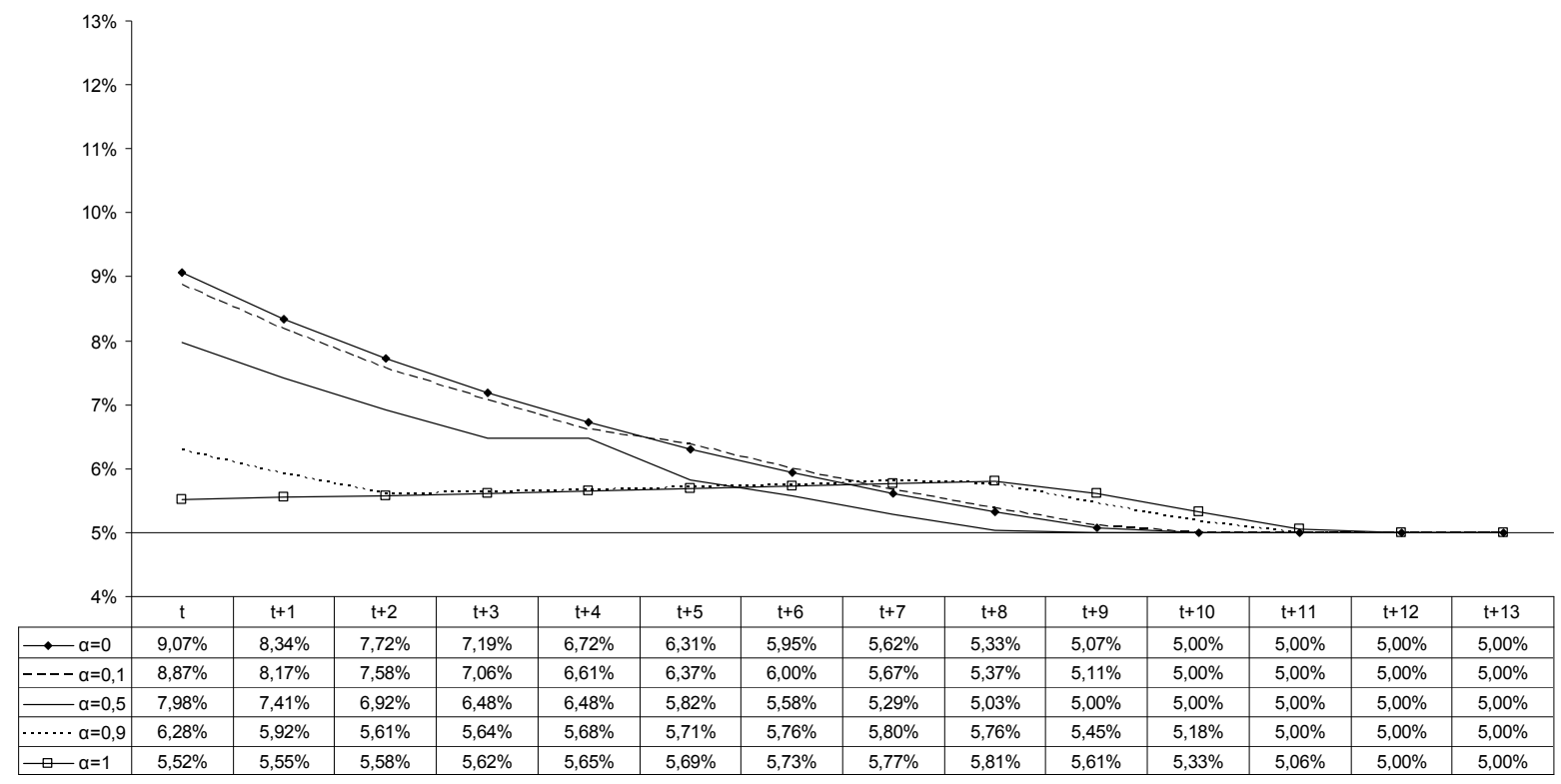

Figure 4. The stock of capital following a new share issue for different values of $\alpha, \tau=.15$

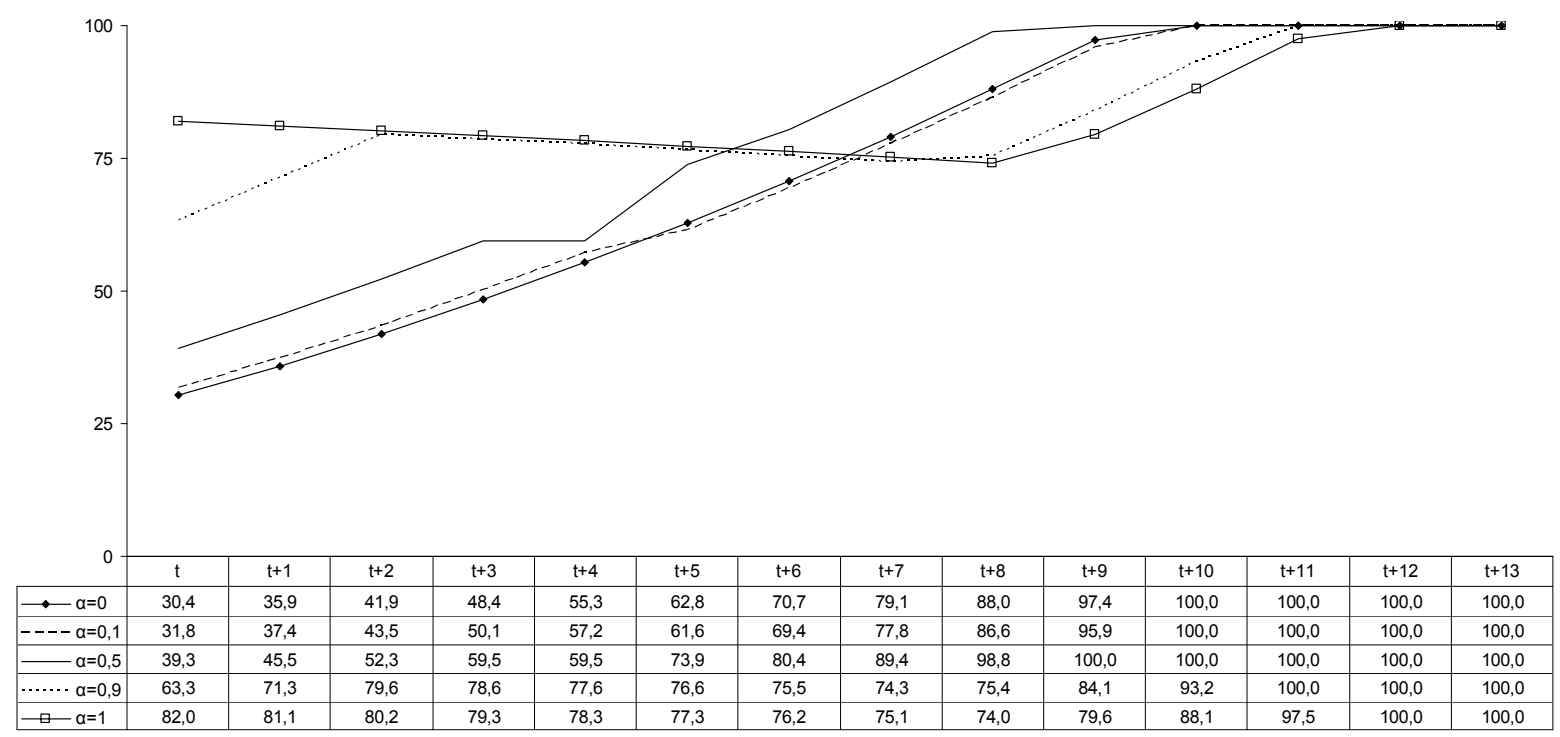


As we have explained in section 3, a rather different approach to share repurchases is taken in Sinn (1991b). A fixed relationship is imposed between share repurchases and dividends. It is easily seen that this assumption is tantamount to a reduction in the dividend tax rate, equal to the proportion of the firm's cash flow which is distributed as tax-free share repurchases. The impact on the cost of capital and the firm's capital stock when share repurchases and dividends occur in equal proportions, may therefore be directly inferred by comparing figures 1 and 2, for $\tau=0.3$ and $\alpha=0$, to figures 3 and 4, for $\tau=0.15$ and $\alpha=0$. As the result of this "tax cut" through share repurchases, the initial injection of equity is doubled, and the adjustment period is shorted by almost one third.

\section{Concluding comments}

In several contributions, Sinn (1991a, c) has argued that the firm's cost of capital depends not only on the source of funds, but also on the firm's use of profits. In our re-examination of the effects of dividend taxation on the cost of new share issues, we have emphasized a third factor, namely the importance of taking into account also the tax treatment of the return of the original capital injected into the firm by the shareholders.

Earlier literature has implicitly or explicitly introduced varying assumptions on the tax consequences of a return of shareholders' capital. In his nucleus theory of the corporation, Sinn (1991a) constrains new issues to be non-negative and rules out share repurchases. These assumptions, which are common in tax models of the firm, effectively turn the dividend tax into a combination of a tax on (distributed) profits and a capital levy on issues of new equity. In contrast, models in the King and Fullerton (1984) tradition implicitly assume that shareholders are allowed a tax-free recovery of their initial equity. This implies that the dividend tax is confined to be a tax on (distributed) profits. Put differently, new share issues never fall into the equity trap.

Sinn's (1991a) criticism of the King and Fullerton methodology for underestimating the cost of new equity thus amounts to a comparison across two different tax regimes. By emphasizing differences in the assumed use of profits - dividends vs. retentions - his criticism is also misleading. Though the firm's dividend behaviour following a new share issue does affect the cost of capital, our analysis shows that the direction of this effect is opposite to that suggested by Sinn: With no dividends being paid, the cost of capital is lower than is the case when 
dividends are paid. This result holds irrespective of the extent to which the firm may escape the equity trap through share repurchases or other forms of tax-free recovery of initial equity.

The firm's behavior following a new share issue crucially depends on the equity trap. When no escape is available, as assumed in Sinn's analysis, the firm will embark upon a growth path following the new issue, using retained earnings as the source of funds. The growth path is instead preceded by a phase of share repurchases when the tax code allows the full amount contributed by the shareholders to be returned free of tax. Our numerical simulations indicate a substantial difference between these cases in the amount of initial equity injections, and a resulting difference in the output losses over the adjustment periods.

When the tax code is less generous, allowing some tax-free return of equity, our analysis indicates that the firm will instead embark upon an investment path, following the injection of capital. This initial growth phase is then followed by a phase of share repurchases, succeeded in turn by a second phase of investment on the firm's way towards long-run equilibrium. We find moreover that the less generous the scope for share repurchases, the longer is the first investment phase and the shorter is the phase of share repurchases.

The model presented in section 2 allows the firm to optimize the timing and amount of share repurchases, and we find that share repurchases will always precede the payment of dividends. In Sinn's approach to share repurchases (1991b), however, share repurchases and dividends by assumption occur in a fixed proportion. As demonstrated in section 3 , and also pointed out by Sinn, this is tantamount to reducing the dividend tax rate. Once this equivalence is understood, no additional insights about the effects of share repurchases are offered from his approach.

In conclusion, we emphasize that the choice between Sinn’s (1991a) and King and Fullerton's assumptions about the equity trap, as well as between the intermediate cases, is ultimately an empirical question. It is clearly the case that techniques such as share repurchases and combinations of splits and share redemptions, have gained in importance in most countries since the 1990s. Though the tax code varies across countries, most countries would also allow shareholders a tax-free recovery of their initial equity following a winding-up decision. These procedures may trigger capital gains taxation, but the deductibility of the acquisition costs of 
shares sold or redeemed ensures that the original contributions of equity capital to a large extent do escape the equity trap.

\section{References}

Auerbach, Alan J., 1979, Wealth Maximization and the Cost of Capital, Quarterly Journal of Economics, Vol.93(3), pp. 433-446.

Auerbach, Alan J., 1983, Taxation, Corporate Financial Policy and the Cost of Capital, Journal of Economic Literature, Vol. 21, No. 3. (Sep., 1983), pp. 905-940.

Auerbach, Alan J., 2002, Taxation and Corporate Financial Policy, in Handbook of Public Economics, Vol. 3, Ch. 19, pp 1251-1292.

Auerbach, Alan J. and Kevin Hassett, 2002, On the marginal source of investment funds, Journal of Public Economics, Vol. 89, pp. 205-232.

Auerbach, Alan J. and Kevin Hassett, 2005, The 2003 dividend tax cuts and the value of the firm: An event study, NBER WP 11449.

Bradford, David F., 1981, The Incidence and Allocation Effects of a Tax on Corporate Distributions, Journal of Public Economics, Vol. 15, pp. 1-22.

Directive 77/91/EEC (The Council of the European Communities)

Directive 92/101/EEC (The Council of the European Communities)

Devereux, M. P. and R. Griffith, 2003, Evaluating tax policy for location decisions, International Tax and Public Finance,10, pp. 107-126.

Devereux, M. P., R. Griffith and A. Klemm, 2002, Corporate income tax reforms and international tax competition” Economic Policy, 35, pp. 451-495. 
EU (2001), Company taxation in the internal market, Commission staff working paper, COM(2001) 582 final.

King, M. A., 1977, Public Policy and the Corporation (Chapman and Hall, London).

King, M. A. and D. Fullerton, 1984, The Taxation of Income from Capital. A Comparative Study of the United States, the United Kingdom, Sweden and West-Germany (University of Chicago Press, Chicago).

Lindhe, Tobias and Södersten, Jan, 2006, The Equity Trap, the Cost of Capital and the Firm's Growth Path, CESifo Working Paper no. 1801.

OECD (1991), Taxing Profits in a Global Economy: Domestic and International Issues (OECD Publications, Paris).

Sinn, Hans-Werner, 1991a, The vanishing Harberger triangle, Journal of Public Economics, Vol. 45, pp. 271-299.

Sinn, Hans-Werner, 1991b, Share Repurchases, the 'New' View and the Cost of Capital, Economics Letters 36, 1991, pp. 187-190.

Sinn, Hans-Werner, 1991c, Taxation and the Cost of Capital: The 'Old' View, the 'New' View, and another View, in Bradford, D. (ed.), 1991, Tax Policy and the Economy 5, (MIT Press, Cambridge)

Sørensen, Peter Birch (ed.), 2004, Measuring the Tax Burden on Capital and Labor, CESifo Seminar Series, (MIT Press, Cambridge. Massachusetts, London).

Chennells, L. and R. Griffith, 1987, Taxing Profits in a Changing World, (IFS: London). Jorgenson, Dale and Ralph Landau (eds.), 1993, Tax Reform and the Cost of Capital. An International Comparison, (The Brookings Institution, Washington, D.C.) 


\section{Appendix: Details on the simulation of the growth path}

The numerical simulations reported in section 4 make use of the first order conditions to determine the development over time of the marginal valuation of capital, $\mu^{K}$, the pre-tax marginal rate of return, $F_{K}$, and the capital stock, $K$. The simulations also require a specification of the firm's production function. We let

$$
F(K)=C K^{\rho}
$$

represent the firm's output, where $C$ determines the level of technology, and $\rho$ is capital's share of output. With $\rho=0.5, C=1$ and the market interest rate $r=0.05$, the long-run capital stock, as determined by $F_{K}=r$ (eq. 19), is $K=100$.

For $\alpha=0$, the model replicates Sinn's analyses. Since the firm's starting condition for period $t$ is that the marginal valuation of capital equals unity, the simulation starts by choosing, tentatively, a value for the marginal valuation of capital for the next period, $\mu_{t+1}^{K}<1$. From the general cost-of-capital expression (18), and the production function (A1) the initial capital stock, $K_{t}$, is calculated. By adding investment equal to $I_{t+1}=F\left(K_{t}\right)$, we obtain the capital stock $K_{t+1}=K_{t}+I_{t+1}$ (eq. 3), the marginal productivity $F_{K_{t+1}}=\rho C K_{t+1}^{\rho-1}$ (eq. A1) and the marginal valuation of capital $\mu_{t+2}^{K}=\mu_{t+1}^{K} \frac{1+r}{1+F_{K_{t+1}}}$ (eq. 18). This stepwise procedure is continued until the marginal productivity of capital equals the rate of interest. If the marginal valuation of capital happens to exceed (fall below) $\theta$, the simulation procedure is repeated, picking a lower (higher) starting value for $\mu_{t+1}^{K}$.

With $\alpha=1$,we find that (footnote 10) $\lambda_{s}^{N}=0$ and $\lambda_{s}^{R}=0$ for all time periods $s$. Further, a new share issue at time $t$ implies a positive stock of new equity, i.e. $A_{t}>0$, and, because of this $G_{t}<A_{t}$ and $\lambda_{t}^{G}=0$. By the first order conditions for $N$ and $A$ (eqs. 14 and 15), we then derive

$$
\mu_{t+1}^{K}=\mu_{t}^{K}(1+r)-r=\mu_{t}^{K}-r\left(1-\mu_{t}^{K}\right)<\mu_{t}^{K},
$$


As explained in section 4 , the only feasible use of profits for period $t+1$ is for repayment of the initial issue of equity, i.e. $R_{t+1}>0$ and $\lambda_{t+1}^{R}=0$. Assuming first that repayment takes place gradually, i.e. $0<G_{t+1}<A_{t+1}$ and $\lambda_{t+1}^{G}=0$, we may use (A2) and an updated version of (27) to solve for the firm's capital stock, $K_{t+1}$, and also the stock of repurchases $G_{t+1}$. Since $\lambda_{t+1}^{G}=0$ implies that $K_{t+1}<K_{t}$ (see p. 14), this partial repayment of the original issue of equity is financed both by current profits and disinvestment. Alternatively, the firm may choose to repay the entire issue of new equity at time $t+1$, by a further reduction in the stock of capital. However, such a reduction is not compatible with the first order conditions, since $\lambda_{t+1}^{G}>0$ when $G_{t+1}=A_{t+1}$, yields a lower cost of capital, implying a larger capital stock. Repaying the entire issue of equity at time $t+1$ is therefore ruled out.

In the simulation we begin by choosing, tentatively, a starting value for $\mu_{t}^{K}$ in the feasible interval $\theta<\mu_{t}^{K}<1$. With $\lambda_{t}^{G}=0$ we determine $\mu_{t+1}^{K}$ from (A2) and solve for the initial stock of capital implicitly given by the cost-of-capital expression $F_{K_{t}}=r / \mu_{t+1}^{K}$ (eq. 27). The capital stock in period $t$ will be fully efficient in production in period $t+1$ and generate profit $F\left(K_{t}\right)$ in that period. Since $\lambda_{t+1}^{G}=0$ when $G_{t+1}<A_{t+1}$, we use an updated version of (A2) to compute $\mu_{t+2}^{K}$, and solve for the firm's capital stock, $K_{t+1}$, implicitly given by an updated version of (27). We also account for profits $F\left(K_{t+1}\right)$ and the stock of repurchased equity $G_{t+1}$. Repayment takes place gradually, and if profits in, say, time period $s-1$, is insufficient to return the remaining stock of new equity, i.e. $F\left(K_{s-2}\right)<G_{s-1}-A_{s-1}$, a positive stock will be kept for the following period, and the abovementioned procedure is repeated. If, on the other hand, $F\left(K_{s-2}\right) \geq G_{s-1}-A_{s-1}$, the return of the initial equity issue will be completed in period $s$, possibly in conjunction with an addition to the capital stock (if $F\left(K_{s-2}\right)>G_{s-1}-A_{s-1}$ ), which will terminate the phase of share repurchases. In the second phase (which follows the case where $\alpha=0$ ), having repaid the new equity, the firm uses all of the profits earned in subsequent periods for investment, which means that we add $I_{v}=F\left(K_{v-1}\right), v=s+1, s+2 \ldots$. 
to the capital stock of the previous year, $K_{v-1}$ (cf. eq. 3). This "growth phase" is continued until the marginal productivity of capital is equated to the rate of interest. Again, if the marginal valuation of capital in the first round of simulations then happens to exceed (fall below) $\theta$, the whole procedure is repeated, using a lower (higher) starting value for $\mu_{t}^{K}$.

In the intermediate case where $0<\alpha<1$, optimal behavior is different. When the firm issues new shares in period $t$, the non-negativity constraint on share repurchases will bind, $\lambda_{t}^{R}>0$, just as is the case where $\alpha=1$, see p. 15 above. However, for the following periods, our numerical simulations strongly suggest that profits will be used for investment rather repurchases, that is $\lambda_{t+1}^{R}>0$. On theoretical grounds, we cannot rule out the possibility that the firm will repurchase shares in period $t+1$, but such behavior would violate the firm's budget constraint: The first-order conditions with $\lambda_{t+1}^{R}=0$ imply an increase in the capital stock between periods $t$ and $t+1$ that clearly exceeds current profits.

Compared to the cases where $\alpha$ equals zero or unity we now exogenously choose starting values for both $\mu_{t}^{K}$ and $\mu_{t+1}^{K}$. The range of this choice is narrowed in two ways. From the first order conditions, we find that in the long-run $\mu^{A}=\alpha \tau$. Since this marginal valuation of the stock of past equity injections falls over time from period $t$ and onwards, it must then hold that $\mu_{t}^{A}<\alpha \tau$. Hence, by (12) and (14) and with $\lambda_{t}^{N}=0$, we require that $\mu_{t}^{K}>1-\alpha \tau$. Moreover, the marginal valuations $\mu_{t}^{K}$ and $\mu_{t+1}^{K}$ must be chosen such that the shadow price of the non-negativity constraint on share repurchases (derived from (22) above)

$\lambda_{s+1}^{R}=\frac{1+r}{\alpha}\left(1-\mu_{s}^{K}\right)-\left(1-\mu_{s+1}^{K}\right)$

declines over time. This implies that at some period of time $\lambda^{R}=0$, that is, the firm will start repurchasing shares (otherwise the firm would grow indefinitely and would never distribute any profits).

From the general cost-of-capital expression (18), the initial marginal valuations $\mu_{t}^{K}$ and $\mu_{t+1}^{K}$ determine both the initial new share issue and the capital stock, $K_{t}$. During this first 
phase profit is retained and invested, $I_{t+1}=F\left(K_{t}\right)$, adding to the capital stock $K_{t+1}=K_{t}+I_{t+1}$. Using (eq. A1) we also derive the marginal productivity of capital $F_{K_{t+1}}=\rho C K_{t+1}^{\rho-1}$ and the marginal valuation of capital $\mu_{t+2}^{K}=\mu_{t+1}^{K} \frac{1+r}{1+F_{K_{t+1}}}$. This stepwise procedure is repeated until $\lambda^{R}=0$.

In the next phase, the firm uses its profits and some disinvestment for repurchasing equity. With $\lambda^{R}=0$ for two consecutive periods, and a non-binding stock constraint on share repurchases, $\lambda^{G}=0$, it is straightforward to demonstrate that the marginal valuation of capital falls over time according to (A2). The cost of capital is then, $F_{K_{s}}=r / \mu_{s+1}^{K}$, independent of $\alpha$, which implies a shrinking capital stock. The firm will continue to repurchase equity until (in say period $v$ ) the stock constraint, defined as $\alpha A_{v}$ is reached. If $F\left(K_{v-1}\right)>G_{v-1}-\alpha A_{v-1}$ the repayment of equity is finished $\left(G_{v}=\alpha A_{v}\right)$ in conjunction with an addition to the capital stock.

The firm will then use profits earned in subsequent periods for investment, i.e. a second investment phase is entered, which means that we add current profits to the capital stock of the previous year. Again, the "growth process" is continued until the marginal productivity of capital is equated to the rate of interest. If the marginal valuation of capital in the first round of simulations then happens to exceed or fall below $\theta$, the whole procedure is repeated, using new starting values for $\mu_{t}^{K}$ and $\mu_{t+1}^{K}$. 
WORKING PAPERS*

Editor: Nils Gottfries

2007:27 Olof Åslund and Oskar Nordström Skans, How to Measure Segregation Conditional on the Distribution of Covariates. 17pp.

2007:28 Che-Yuan Liang, Is There an Incumbency Advantage or a Cost of Ruling in Proportional Election Systems? 20pp.

2007:29 Stefan Eriksson and Jonas Lagerström, Detecting discrimination in the hiring process: Evidence from an Internet-based search channel. 31pp.

2007:30 Helge Berger and Pär Österholm, Does Money Growth Granger-Cause Inflation in the Euro Area? Evidence from Out-of-Sample Forecasts Using Bayesian VARs. 32pp.

2007:31 Ranjula Bali Swain and Maria Floro, Effect of Microfinance on Vulnerability, Poverty and Risk in Low Income Households. 35pp.

2008:1 Mikael Carlsson, Johan Lyhagen and Pär Österholm, Testing for Purchasing Power Parity in Cointegrated Panels. 20pp.

2008:2 Che-Yuan Liang, Collective Lobbying in Politics: Theory and Empirical Evidence from Sweden. 37pp.

2008:3 Spencer Dale, Athanasios Orphanides and Pär Österholm, Imperfect Central Bank Communication: Information versus Distraction. 33pp.

2008:4 Matz Dahlberg and Eva Mörk, Is there an election cycle in public employment? Separating time effects from election year effects. 29pp.

2008:5 Ranjula Bali Swain and Adel Varghese, Does Self Help Group Participation Lead to Asset Creation. 25pp.

2008:6 Niklas Bengtsson, Do Protestant Aid Organizations Aid Protestants Only? $28 \mathrm{pp}$.

2008:7 Mikael Elinder, Henrik Jordahl and Panu Poutvaara, Selfish and Prospective Theory and Evidence of Pocketbook Voting. 31pp.

2008:8 Erik Glans, The effect of changes in the replacement rate on partial retirement in Sweden. 30pp.

2008:9 Erik Glans, Retirement patterns during the Swedish pension reform. 44pp.

2008:10 Stefan Eriksson and Jonas Lageström, The Labor Market Consequences of Gender Differences in Job Search. 16pp.

\footnotetext{
* A list of papers in this series from earlier years will be sent on request by the department.
} 
2008:11 Ranjula Bali Swain and Fan Yang Wallentin, Economic or Non-Economic Factors - What Empowers Women?. 34pp.

2008:12 Matz Dahlberg, Heléne Lundqvist and Eva Mörk, Intergovernmental Grants and Bureaucratic Power. 34pp.

2008:13 Matz Dahlberg, Kajsa Johansson and Eva Mörk, On mandatory activation of welfare receivers. 39pp.

2008:14 Magnus Gustavsson, A Longitudinal Analysis of Within-Education-Group Earnings Inequality. 26pp.

2008:15 Henrique S. Basso, Delegation, Time Inconsistency and Sustainable Equilibrium. 24pp.

2008:16 Sören Blomquist and Håkan Selin, Hourly Wage Rate and Taxable Labor Income Responsiveness to Changes in Marginal Tax Rates. 31 pp.

2008:17 Jie Chen and Aiyong Zhu, The relationship between housing investment and economic growth in China : A panel analysis using quarterly provincial data. $26 \mathrm{pp}$.

2009:1 Per Engström, Patrik Hesselius and Bertil Holmlund, Vacancy Referrals, Job Search, and the Duration of Unemployment: A Randomized Experiment. $25 \mathrm{pp}$.

2009:2 Chuan-Zhong Li and Gunnar Isacsson, Valuing urban accessibility and air quality in Sweden: A regional welfare analysis. 24pp.

2009:3 Luca Micheletto, Optimal nonlinear redistributive taxation and public good provision in an economy with Veblen effects. $26 \mathrm{pp}$.

2009:4 Håkan Selin, The Rise in Female Employment and the Role of Tax Incentives. An Empirical Analysis of the Swedish Individual Tax Reform of $1971.38 \mathrm{pp}$.

2009:5 Lars M. Johansson and Jan Pettersson, Tied Aid, Trade-Facilitating Aid or Trade-Diverting Aid? 47pp.

2009:6 Håkan Selin, Marginal tax rates and tax-favoured pension savings of the selfemployed Evidence from Sweden. 32pp.

2009:7 Tobias Lindhe and Jan Södersten, Dividend taxation, share repurchases and the equity trap. $27 \mathrm{pp}$.

See also working papers published by the Office of Labour Market Policy Evaluation http://www.ifau.se/ 